\title{
РЕШЕНИЯ КОНСТИТУЦИОННОГО СУДА РОССИЙСКОЙ ФЕДЕРАЦИИ: ПРОБЛЕМЫ ИСПОЛНЕНИЯ
}

\begin{abstract}
Аннотация: Предметом исследования в настоящей статье являются общественные отношения, связанные с исполнением решений Конституциинного Суда Российской Федераџии. В статье рассматриваются вопросы юридической силь решений Конституционного Суда Российской Федераџии, их непосредственного действия, правовой механизм исполнения решений органов конституционного контроля, включая обязанность компетентных органов по внесению изменений в законодательство в соответствии с правовыми позициями Конституционного Суда, а так жевопросы ответственности за неисполнение решений Конституционного Суда Российской Федеращии. В процессе исследования автором использовались какобщенаучные методы исследования, так и частно-научные, включаяметод сравнительного правоведения, научного анализа, синтеза. Автор, используя указанные методы, пришел к выводам о том, что действующее законодательство не предусматривает порядок реализации решений Конституционного Суда Российской Федерации, но предусматривает обязанность государственных органов и должностных лиц приводить в соответствие с Конституцчией и правовыми позициями Конституцчионного Суда нормативно-правовые акты, признанные судом не соответствуюшими Конституцчии. В связи с этим возникает необходимость корректировки действующего законодательства, регулирующего вопросы исполнения решений Конституционного Суда. При этом, по мнению автора принятие отдельного закона, регламентирующего такое исполнение, не целесообразно.
\end{abstract}

Ключевые слова: Исполнение, эффективность, судебная власть, судебные органы, конституционньй контроль, Конституциионый Суд, Конституция, ответственность, права, свободьл.

Abstract: The subject of this research is the public relations pertaining to executions of the decisions of the Constitutional Court of the Russian Federation. The article examines the questions of juridical power of the decisions of the Constitutions Court of the Russian Federation, their direct effect, the legal mechanism of the execution of the decisions of the branches of constitutional review, including the duties of the competent branches on amendments to the legislation in accord with the legal positions of the Constitutional Court, as well as the questions of responsibility for failure to carry out the decisions of the Constitutional Court of the Russian Federation. The author concludes that the current legislation does not provide the order of implementation of the decisions of the Constitutional Court of the Russian Federation, but does hold responsible the government branches and officials for execution of the normative legal acts in accordance with the Constitution and the legal position of the Constitutional Court that are ruled by the court as unconstitutional. Due to this fact, there is a need for correction of the current legislation that regulates the questions of execution of the decisions of the Constitutional Court.

Keywords: Rights, Responsibility, Constitution, Constitutional Court, Judicial system, Constitutional review, Judicial authority, Efficiency, Execution, Liberties.

дним из важнейших критериев эффективности деятельности Конституционного Суда Российской Федерации в правозащитной сфере является критерий исполнимости его решений.

Ученые отмечают: «Происходящие в стране экономические преобразования, переход к рыночной реформе хозяйствования предопределили насущную необходимость в судебной реформе, одним из частных вопросов которой стала проблема невозможности эффективного принудительного исполнения судебных актов и актов других органов. Низкий уровень исполнения судебных решений уже давно был тревожным симптомом тяжелого недуга правоисполнительной структуры»[1].

Однако данная проблема актуальна не только для судов общей юрисдикции и арбитражных судов, но и для Конституционного Суда Российской Федерации. На наш взгляд, пока существует проблема неисполне- ния решений органов конституционного контроля, уровень конституционной судебной защиты прав и свобод человека и гражданина нельзя считать надлежащим.

По проблеме исполнения судебных актов органа конституционного контроля ведутся дискуссии как в самом Конституционном Суде, так и в иных государственных органах.

Так, Президент Российской Федерации в Послании Федеральному Собранию Российской Федерации от 05.11.2008 отметил, что «исполнение судебных решений - все еще огромная проблема. Причем проблема всех судов, включая Конституционный»[2]. Как указывает В. Д. Зорькин, «накоплено много материалов по неисполнению решений Конституционного Суда всеми уровнями власти, в том числе и законодательной. Есть примеры, когда в течение двух лет законодатель не реагировал на решения Суда. Наше решение, по большому счету, не требует подтверждения 


\section{Право и политика $12(192) \cdot 2015$}

каких-либо других органов, оно должно быть исполнено»[3; 101]. Безусловно, при таких обстоятельствах невозможно говорить о должном уровне обеспечения и защиты прав и свобод человека и гражданина в Конституционном Суде.

В соответствии с Положением о мониторинге правоприменения в Российской Федерации, утвержденным Указом Президента РФ от 20.05.2011 № 657 «О мониторинге правоприменения в Российской Федерации», Министерство юстиции Российской Федерации осуществляет в установленной сфере деятельности мониторинг правоприменения в Российской Федерации в целях выполнения решений Конституционного Суда Российской Федерации[4]. Так, по данным Министерства юстиции, «с 1 января 1992 г. по 21 августа 2014 г. Конституционным Судом Российской Федерации принято 157 постановлений, в соответствии с которыми признаются не соответствующими Конституции Российской Федерации отдельные положения федеральных законов и федеральному законодателю надлежит исходя из требований Конституции Российской Федерации и основанных на них правовых позициях Конституционного Суда Российской Федерации внести соответствующие изменения в нормативные правовые акты Российской Федерации, в том числе в 2013 г. - 23 решения, в первом полугодии 2014 г. - 12. За период с 1992 года исполнено 123 постановления, в том числе в 2013 году - 25 (увеличение на 28 процентов по сравнению с 2012 годом); в первом полугодии 2014 года - 14»[5].

В аналогичном докладе за 2012 год Министерством юстиции РФ указывается, что по состоянию на 15 июля 2013 г. требуют выполнения 34 постановления Конституционного Суда[6]. Сопоставив данные доклады, можно заметить, что в 2013 году остались неисполненными как минимум девять постановлений органа конституционного контроля.

Таким образом, как видно из приведенных данных, в настоящее время не все постановления Конституционного Суда Российской Федерации, принятые с 1992 года, были исполнены. Наличие неисполненных постановлений органа конституционного контроля, на наш взгляд, негативным образом отражается как на общем уровне защищенности прав и свобод человека и гражданина, так и на авторитете Конституционного Суда Российской Федерации.

Говоря о существенном влиянии данной проблемы на состояние защищенности прав и свобод человека и гражданина в Российской Федерации, следует согласиться с мнением Ж. В. Нечаевой, которая заявляет: «Либеральное (неадекватное) отношение к фактам игнорирования или ненадлежащего испол- нения решений Конституционного Суда Российской Федерации, его действующих установок не только наносит огромный ущерб конституционным правам и свободам граждан, основам конституционного строя, интересам правосудия, но и подрывает у граждан доверие к судам и государству в целом»[7].

Обоснованным представляется и утверждение Г.А. Василевича о том, что показателем цивилизованности и готовности общества и государства разрешать все споры исключительно правовыми средствами является исполнение решений органов конституционного контроля в соответствующем государстве[8; 65].

Анализируя вопросы исполнения решений Конституционного Суда Российской Федерации, автор полагает необходимым обратиться, прежде всего, к их нормативному регулированию.

Правовой основой исполнения решений судебных органов конституционного контроля являются правовые нормы, закрепленные в статьях 78-81 Закона о Конституционном Суде.

Так, статьей 78 названного закона устанавливается юридическая сила решения органа конституционного контроля Российской Федерации. В частности, частью 2 данной статьи установлено, что решение Конституционного Суда Российской Федерации действует непосредственно и не требует подтверждения другими органами и должностными лицами. Юридическая сила постановления Конституционного Суда Российской Федерации о признании акта неконституционным не может быть преодолена повторным принятием этого же акта.

При этом, в случае, если решением Конституционного Суда Российской Федерации нормативный акт признан не соответствующим Конституции Российской Федерации полностью или частично либо из решения Конституционного Суда Российской Федерации вытекает необходимость устранения пробела в правовом регулировании, государственный орган или должностное лицо, принявшие этот нормативный акт, рассматривают вопрос о принятии нового нормативного акта, который должен, в частности, содержать положения об отмене нормативного акта, признанного не соответствующим Конституции Российской Федерации полностью, либо о внесении необходимых изменений и (или) дополнений в нормативный акт, признанный неконституционным в отдельной его части[9].

Частью 2 статьи 79 Закона о Конституционном Суде предусмотрено, что решение Конституционного Суда Российской Федерации действует непосредственно и не требует подтверждения другими органами и должностными лицами. По этому поводу исследова- 
DOI: 10.7256/1811-9018.2015.12.17310

При цитировании этой статьи сноска на doi обязательна

Судебная власть

тели отмечают, что постановление Суда действует так же прямо и непосредственно, как и Конституция, а в некоторых случаях такое постановление может даже стимулировать либо усиливать непосредственное действие конституционной (уставной) нормы, в том числе и в случаях, когда признание нормативно-правового акта не соответствующим Конституции РФ порождает пробелы в правовом регулировании общественных отношений[10]. При этом «свойство непосредственности означает самодостаточность решения Суда, отсутствие необходимости подтверждения, верификации со стороны других органов государственной власти. В этом проявляется такая грань Российской Федерации как правового государства, как самокритичный характер государственности, когда КС РФ как органу, осуществляющему судебный конституционный нормоконтроль, вменяется обязанность обеспечивать начала конституционализма в деятельности других органов государственной власти. Неслучайно использованное в тексте Закона о Конституционном Суде РФ понятие “непосредственно действующее” перекликается с положением ст. 18 Конституции РФ о том, что непосредственно действующими являются права и свободы человека и гражданина»[11].

На наш взгляд, вопрос непосредственного действия постановлений органа конституционного контроля прямо связан с вопросом их исполнения. Полагаем, что постановления Конституционного Суда Российской Федерации о признании нормативно-правового акта не соответствующим Конституции являются непосредственно действующими лишь временно, то есть до тех пор, пока они не будут исполнены и не будет принят соответствующий нормативный акт, заполняющий пробел в правовом регулировании, вызванный утратой силы правовых норм по причине признания их неконституционными. На наш взгляд, данный вывод следует из толкования статей 79 и 80 Закона о Конституционном Суде в их взаимосвязи со статьями 1 и 3 данного Закона. Представляется, что после приведения законодательства Российской Федерации в соответствие с решением Конституционного Суда цель конституционного правосудия (защита прав и свобод человека и гражданина, охрана основ конституционного строя) в рамках конкретного дела считается достигнутой и необходимость непосредственного применения решения Конституционного Суда отпадает ввиду устранения пороков правового регулирования спорных правоотношений. Однако это не исключает обязанности судов общей юрисдикции или арбитражных судов пересмотреть в установленном законом порядке принятые решения, основанные на нормах, признанных не соответствующими Конституции Российской Федерации. Именно в случае такого пересмотра, на наш взгляд, достигается первоначальная цель лица, обратившегося в Конституционный Суд за защитой своих прав, состоящая в удовлетворении или отказе в удовлетворении материально-правовых требований.

Как следует из изложенного, постановления Конституционного Суда Российской Федерации являются общеобязательными правоприменительными актами, которые порождают обязанность компетентных органов совершить действия, направленные на устранение правовых пробелов, возникших вследствие признания какого-либо акта не соответствующим Конституции Российской Федерации.

Представляется, что совершение указанных действий не является исполнением решения суда в привычном понимании, поскольку в решении Конституционного Суда не указывается на необходимость осуществления соответствующих действий, а такая обязанность возникает в силу закона. В статье 80 Закона о Конституционном Суде закреплена обязанность государственных органов и должностных лиц по приведению законов и иных нормативных актов в соответствие с Конституцией Российской Федерации в связи с решением Конституционного Суда Российской Федерации.

Согласно статье 81 Закона о Конституционном Суде неисполнение, ненадлежащее исполнение либо воспрепятствование исполнению решения Конституционного Суда Российской Федерации влечет ответственность, установленную федеральным законом. Уголовным законом установлена ответственность за злостное неисполнение судебного акта представителем власти, государственным служащим, муниципальным служащим, а также служащим государственного или муниципального учреждения, коммерческой или иной организации вступивших в законную силу приговора суда, решения суда или иного судебного акта, а равно воспрепятствование их исполнению.

Еще одной мерой ответственности за неисполнение постановлений органа конституционного контроля является предусмотренная Федеральным законом «Об общих принципах организации законодательных (представительных) и исполнительных органов государственной власти субъектов Российской Федерации» возможность Президента Российской Федерации выносить предупреждение законодательному (представительному) органу государственной власти субъекта Российской Федерации или вносить в Государственную Думу проект федерального закона о роспуске законодательного (представи- 
DOI: $10.7256 / 1811-9018.2015 .12 .17310$

При цитировании этой статьи сноска на doi обязательна

\section{Право и политика $12(192) \cdot 2015$}

тельного) органа государственной власти субъекта Российской Федерации за неисполнение решений Конституционного Суда Российской Федерации[12].

Возможность применения указанных норм права в качестве мер ответственности за неисполнение решений Конституционного Суда подтверждена самим Конституционным Судом в Определении от 19.04.2001[13].

Представляется, что ответственность за неисполнение решения Конституционного Суда не должна ограничиваться рамками принятого судебного акта, а должна наступать и вследствие неисполнения обязанности по выявлению и отмене норм права, аналогичных тем, которые были признаны неконституционными Конституционным Судом.

Так, в рассматриваемом Определении Суд указал, что «принцип непосредственного действия решений Конституционного Суда Российской Федерации и положение части второй статьи 87 Федерального конституционного закона “О Конституционном Суде Российской Федерации” обязывают органы государственной власти субъектов Российской Федерации выявлять в своем законодательстве положения, аналогичные тем, которые признаны неконституционными, и отменять их в установленном порядке. Неисполнение этой обязанности также влечет конституционно-правовую ответственность в форме досрочного прекращения полномочий, процедура которого начинается с вынесения Президентом Российской Федерации предупреждения»[13]. Думается, что данный правовой механизм предполагает обеспечение надлежащей реализации и защиты прав и свобод человека и гражданина в Российской Федерации в наибольшей степени.

Однако на практике представляется крайне затруднительным привлечение госслужащих к ответственности за неисполнение решений Конституционного Суда Российской Федерации, в том числе и потому, что такое исполнение предполагает слаженную работу многих госслужащих из различных органов власти (например, в законодательном процессе). Как отмечает Н. В. Витрук в особом мнении к Постановлению Конституционного Суда РФ от 04.04.2002, при такой процедуре применения мер конституционно-правовой ответственности практически невозможно обеспечить действие принципов справедливости, соразмерности меры ответственности характеру содеянного, а приоритетное значение будет иметь принцип партийно-политической и иной целесообразности. Вся процедура применения мер федерального воздействия (кроме, возможно, мер предупреждения, выносимых Президентом Российской
Федерации) настолько сложна и длительна, что если учесть еще возможность всякий раз оспорить в суде каждый ее этап, то станет ясно, что она не рассчитана на реальное применение, а потому теряет всякий смысл и уже в силу этого не соответствует принципам демократического правового государства[14].

Согласимся с мнением Г. А. Гаджиева, который считает, что термин «исполнение решения суда» представляется не вполне корректным. Ученый полагает, что более точным является термин «реализация решений», который обозначает суть взаимоотношений между судом, принявшим судебный акт, и законодателем, который вправе или обязан учитывать этот судебный акт[15].

А. А. Малюшин исследует вопросы реализации решений Конституционного Суда в контексте конституционно-судебного правотворчества через призму форм реализации права: использование, исполнение, применение правовых норм[16].

Использование заключается в действиях управомоченных субъектов по осуществлению закрепленных в нормах субъективных прав. Указанные действия заключаются в использовании возможностей, которые предоставляются субъектам правоотношений соответствующими правовыми нормами. Применительно к деятельности Конституционного Суда использование может означать реализацию уполномоченными органами своих правомочий в соответствии с правовыми позициями органа конституционного контроля. В этой связи видится обоснованной позиция М. Н. Марченко, который отмечает, что «существует значительное различие в осуществлении прав гражданами и использовании правомочий государственными органами и должностными лицами. Использование или неиспользование субъективных прав гражданами является сугубо добровольным делом. Никто не может принуждать их к использованию ими своих прав, и никто не может нести никакой ответственности за неиспользование этих прав. По-иному обстоит дело с осуществлением правомочий государственными органами и должностными лицами. Здесь осуществление является не только правом, но и обязанностью этих органов и должностных лиц»[17; 313].

Исполнение заключается в активных действиях обязанных субъектов по реализации постановлений Конституционного Суда. Как уже было отмечено и следует из приведенных выше норм Закона о Конституционном Суде, такими субъектами, в частности, являются законодательные органы, а также любые другие органы власти в силу общеобязательности решений органа конституционного контроля. Данная форма реализации предполагает исполнение 
DOI: $10.7256 / 1811-9018.2015 .12 .17310$

При цитировании этой статьи сноска на doi обязательна

Судебная власть

конкретных указаний, содержащихся в постановлении Конституционного Суда, например в случае, если Суд определяет обязанность других судов пересмотреть в установленном порядке дела тех граждан, которые обратились с жалобами в Конституционный Суд Российской Федерации, тем самым вынуждая суды осуществить пересмотр соответствующих решений[18]. Однако в отношении реализации решений Конституционного Суда данная форма представляется неоднозначной, поскольку судебные акты и так подлежат пересмотру в случае, если они приняты вразрез с постановлениями органа конституционного контроля. Конституционный Суд указал, что судебные и иные правоприменительные решения, основанные на акте, которому в ходе применения по конкретному делу суд общей юрисдикции или арбитражный суд придал истолкование, расходящееся с его конституционно-правовым смыслом, выявленным Конституционным Судом Российской Федерации и являющимся общеобязательным, подлежат пересмотру в порядке, установленном законом[19].

Применение, по мнению А. А. Малюшина, предполагает осуществление активной правомерной деятельности управомоченных субъектов права. Применение необходимо для того, чтобы наиболее полно обеспечить осуществление конституционных норм, а также для государственного контроля правильности и точности их реализации.

На наш взгляд, несмотря на наличие вышеуказанных форм реализации постановлений Конституционного Суда Российской Федерации, проблема их неисполнения все же остается комплексной, поскольку охватывает все перечисленные формы.

Существование рассматриваемой проблемы часто связывается с отсутствием определенного механизма исполнения решений органа конституционного контроля. Так, в Указе Президента РФ «Об Основных положениях региональной политики в Российской Федерации» в контексте важности обеспечения соответствия норм конституций (уставов), законов и иных нормативных правовых актов субъектов Российской Федерации Конституции Российской Федерации и федеральным законам отмечается, что необходимо определить порядок приведения действующих и вновь принимаемых актов в соответствие с Конституцией Российской Федерации. В данном документе указывается, что «механизмом такого приведения должна стать функционирующая независимая судебная власть, способная оперативно и непредвзято рассматривать споры между федеральными органами государственной власти и органами государственной власти субъектов Российской Федерации. Особая роль здесь принадлежит Конституционному Суду Российской Федерации, для повышения эффективности работы которого следует законодательно определить порядок реализации его решений»[20].

Как следует из правовых норм, касающихся исполнения постановлений Конституционного Суда Российской Федерации, в действующем законодательстве существуют лишь нормы, устанавливающие общеобязательность решений Конституционного Суда и ответственность за их неисполнение.

Порядок реализации решений Конституционного Суда в настоящее время законодательно не закреплен, поэтому представляется необходимым исследовать вопрос о необходимости его закрепления.

Как отмечается в научной литературе, в Российской Федерации ранее уже предпринимались попытки конкретизировать и узаконить механизм исполнения решений Конституционного Суда РФ. Одна из таких попыток была предпринята в 1997 году в ходе составления проектов федеральных законов об исполнении судебных решений в целом. Конституционный Суд РФ выступил против включения в закон норм, регламентирующих исполнение его собственных решений, аргументируя свою позицию тем, что его постановления по своей сути отличаются от решений других судов и, как и сам закон, обязательны для исполнения без каких бы то ни было действий со стороны судебных приставов[21].

Еще одним шагом на пути регламентации исполнения постановлений органа конституционного контроля стало принятие Федерального конституционного закона от 15.12.2001 № 4-ФКЗ, которым были установлены конкретные сроки исполнения обязанности органов и должностных лиц приводить законодательство в соответствие с Конституцией Российской Федерации в связи с решением Конституционного Суда Российской Федерации (статья 80 Закона о Конституционном Суде)[22].

В научной литературе встречается как поддержка, так и критика указанных поправок. Как отмечают ученые, в данном Законе был учтен опыт деятельности Конституционного Суда РФ и усовершенствован механизм исполнения судебных решений, который будет способствовать гармонизации правового поля России[23].

По мнению Т. Г. Морщаковой, данные поправки ставят под сомнение обязательность постановлений органа конституционного контроля, поскольку их исполнение будет находиться в зависимости от согласия других государственных институтов отменить признанную неконституционной норму или принять новую норму в соответствии с правовой позицией Конституционного Суда[24; 102]. 
DOI: $10.7256 / 1811-9018.2015 .12 .17310$

При цитировании этой статьи сноска на doi обязательна

\section{Право и политика $12(192) \cdot 2015$}

Как считает А. В. Мазуров, статья 80 Закона о Конституционном Суде в прежней редакции, предусматривающей, что решение Конституционного Суда подлежит исполнению немедленно после опубликования либо вручения его официального текста, практически ничего не добавляла к смыслу статьи 12, части 1 статьи 75 и статьи 79 Закона и не могла «заставить» надлежащим образом исполнять многие решения Конституционного Суда. Изложение статьи 80 в новой (действующей) редакции в большей степени способствует исполнению его решений, укреплению авторитета Конституционного Суда и усилению судебной власти. Фактически она установила, что под исполнением решения Конституционного Суда следует понимать приведение неконституционного положения в соответствие с Конституцией[25].

Полагаем, что статью 80 Закона о Конституционном Суде, устанавливающую конкретные сроки приведения законодательства в соответствие с Конституцией РФ и постановлениями Конституционного Суда РФ, не следует рассматривать как дестабилизирующую авторитет Конституционного Суда и ставящую под сомнение обязательность его постановлений, поскольку в данной статье «закреплена обязанность различных органов в зависимости от вида и юридической силы нормативных правовых актов подготовить к принятию новый нормативный правовой акт или изменения в действующий нормативный правовой акт, признанный Конституционным Судом неконституционным»[26].

Исследователи отмечают, что рассматриваемая норма сама по себе не вызвала положительной динамики в решении проблемы исполнения решений органа конституционного контроля. Такой позиции придерживается М. А. Александрова, ссылаясь на запрос Государственной Думы к Председателю Правительства РФ «О необходимости принятия Правительством Российской Федерации мер по внесению изменений в законодательство Российской Федерации во исполнение решений Конституционного Суда Российской Федерации»[27].

А. А. Петров полагает: «Далеко не всегда исполняются предписания новой статьи 80 Закона о Конституционном Суде о порядке исполнения решений Конституционного Суда, введенной Федеральным конституционным законом от 15 декабря 2001 г. № 4-ФКЗ»[28].

На наш взгляд, в контексте необходимости повышения эффективности реализации решений Конституционного Суда обоснованным является мнение А. Н. Кокотова о том, что «разработка законов, устраняющих пробелы правового регулирования (тем более если необходимо подготовить концептуально новый закон или внести системные изменения в разные акты), требует согласованных действий множества субъектов в значительный промежуток времени... При этом целесообразно нормативно установить, что Правительство РФ не позднее чем в двухмесячный срок после опубликования решения КС РФ утверждает своим решением срок подготовки и внесения законопроекта в Государственную Думу. В этот же период данный законопроект должен включаться в план законопроектной работы Правительства РФ с определением головной организации по его разработке, а также должны осуществляться и иные подготовительные действия, в том числе формирование рабочих групп, которые непосредственно будут готовить законопроекты»[29]. Полагаем, что подобные положения могут быть закреплены в Регламенте Правительства Российской Федерации.

Однако следует отметить, что правила, содержащиеся в статье 80 Закона о Конституционном Суде, не предусматривают обязанности органов законодательной власти Российской Федерации самостоятельно принимать меры, направленные на реализацию постановлений органа конституционного контроля. В этой связи представляется обоснованной позиция Н. С. Бондаря, который указывает, что законодательное определение Правительства Российской Федерации как специального субъекта, ответственного за инициирование законодательного процесса в связи с необходимостью исполнения того или иного постановления или определения федерального органа конституционного правосудия, является лишь дополнительной гарантией соблюдения конституционного правопорядка и не исключает обязанности федерального законодателя - при бездействии Правительства Российской Федерации или затягивании им внесения в Государственную Думу проекта соответствующего закона - самостоятельно принять меры к исполнению решения Конституционного Суда Российской Федерации[30; 85].

Для устранения данного правового пробела полагаем необходимым внести изменения в действующую редакцию статьи 80 Закона о Конституционном Суде, дополнив ее пунктом, закрепляющим обязанность Государственной Думы Федерального Собрания Российской Федерации самостоятельно инициировать приведение законов в соответствие с Конституцией и постановлениями Конституционного Суда Российской Федерации в случае нарушения Правительством Российской Федерации сроков, установленных пунктом 1 указанной статьи Закона о Конституционном Суде. 
DOI: $10.7256 / 1811-9018.2015 .12 .17310$

При цитировании этой статьи сноска на doi обязательна

Судебная власть

Таким образом, можно констатировать, что действующее законодательство не предусматривает порядок реализации решений Конституционного Суда Российской Федерации, но предусматривает обязанность государственных органов и должностных лиц приводить в соответствие с Конституцией и правовыми позициями Конституционного Суда нормативно-правовые акты, признанные судом не соответствующими Конституции.

На наш взгляд, смысл выражения «порядок реализации решений Конституционного Суда» предполагает принятие закона, по своей сути и предназначению аналогичного Федеральному закону от 02.10.2007 № 229-Ф3 «Об исполнительном производстве»[31]. Однако принятие подобного закона, содержащего конкретный порядок исполнения решений Конституционного Суда, представляется нам неоправданным в силу правовой природы решений Конституционного Суда. Закон об исполнительном производстве принят в целях обеспечения исполнения судебных актов и актов иных органов и долж- ностных лиц, которые обязательны только для лиц, участвующих в деле. Юридическая сила постановлений Конституционного Суда Российской Федерации в силу их общеобязательности выше, чем юридическая сила решений указанных судебных и иных органов, то есть постановления Конституционного Суда имеют нормативный характер. При этом Конституционный Суд РФ решает только вопросы права, его решения влекут исключительно юридические последствия и не принимаются в отношении материально-правовых требований лиц, обратившихся за защитой прав и интересов в Конституционный Суд. В любом случае материально-правовые последствия наступают после принятия судебного акта судом общей юрисдикции или арбитражным судом, для исполнения которых предусмотрена процедура исполнительного производства. При таких обстоятельствах, полагаем, необходимость принятия отдельного закона, регламентирующего порядок исполнения постановлений органа конституционного контроля, отсутствует.

\section{Библиография:}

1. Вставская И. М., Савченко С. А. Исполнительное производство: Учеб. пособие. 2-е изд., перераб. и доп. М.: Проспект, 2010. Доступ из СПС «Консультант Плюс» (дата обращения: 12.11.2015).

2. Послание Президента РФ Федеральному Собранию от 05.11.2008 // Российская газета. 06.11.2008. № 230. Доступ из СПС «Консультант Плюс» (дата обращения: 12.11.2015).

3. Зорькин В. Д. Россия и Конституция в ХХІ веке. Взгляд с Ильинки. М., 2007.

4. Указ Президента РФ от 20.05.2011 № 657 (ред. от 25.07.2014) «О мониторинге правоприменения в Российской Федерации» (вместе с «Положением о мониторинге правоприменения в Российской Федерации») // Собрание законодательства РФ. 23.05.2011. № 21. Ст. 2930. Доступ из СПС «Консультант Плюс» (дата обращения: 12.11.2015).

5. Доклад о результатах мониторинга правоприменения в Российской Федерации за 2013 год. Доступ из СПС «Консультант Плюс» (дата обращения: 12.11.2015).

6. Доклад о результатах мониторинга правоприменения в Российской Федерации за 2012 год. Доступ из СПС «Консультант Плюс» (дата обращения: 12.11.2015).

7. Нечаева Ж. В. Вопросы эффективности исполнения решений Конституционного Суда Российской Федерации // Журнал конституционного правосудия. 2008. № 5. С. 24-30. Доступ из СПС «Консультант Плюс» (дата обращения: 12.11.2015).

8. Василевич Г. А. Реализация решений Конституционного Суда Республики Беларусь- важное условие формирования современной правовой системы // Национальная государственность и европейские интеграционные процессы: Сб. науч. тр. В 2 т. / Белорус. гос. ун-т. Минск, 2008. Т. 1: Национальное законодательство и его гармонизация с правом Европейского союза.

9. Постановление Конституционного Суда РФ от 14.05.2012 № 11-П «По делу о проверке конституционности положения абзаца второго части первой статьи 446 Гражданского процессуального кодекса Российской Федерации в связи с жалобами граждан Ф. Х. Гумеровой и Ю. А. Шикунова» // Вестник Конституционного Суда РФ. 2012. № 4. Доступ из СПС «Консультант Плюс» (дата обращения: 12.11.2015).

10. Малюшин А. А. Конституционно-судебное правотворчество в Российской Федерации: проблемы теории и практики: Монография. М.: Юрист, 2013. Доступ из СПС «Консультант Плюс» (дата обращения: 12.11.2015).

11. Комментарий к Федеральному конституционному закону «О Конституционном Суде Российской Федерации» (постатейный) / Ю. А. Андреева, В. В. Балытников, Н. С. Бондарь и др.; под ред. Г. А. Гаджиева. М.: Норма: ИНФРА-М, 2012. Доступ из СПС «Консультант Плюс» (дата обращения: 12.11.2015).

12. Федеральный закон от 06.10.1999 № 184-ФЗ (ред. от 25.12.2012) «Об общих принципах организации законодательных (представительных) и исполнительных органов государственной власти субъектов Российской Федерации» (с изм. и доп., вступающими в силу с 27.01.2013) // Собрание законодательства РФ. 18.10.1999. № 42. Ст. 5005. Доступ из СПС «Консультант Плюс» (дата обращения: 12.11.2015).

13. Определение Конституционного Суда РФ от 19.04.2001 «По ходатайству полномочного представителя Президента Российской Федерации в Приволжском федеральном округе об официальном разъяснении определения Конституционного Суда Российской Федерации от 27 июня 2000 года по запросу группы депутатов Государственной 
Думы о проверке соответствия Конституции Российской Федерации отдельных положений конституций Республики Адыгея, Республики Башкортостан, Республики Ингушетия, Республики Коми, Республики Северная Осетия - Алания и Республики Татарстан» // Собрание законодательства РФ. 2001. № 20. Ст. 2059. Доступ из СПС «Консультант Плюс» (дата обращения: 12.11.2015).

14. Постановление Конституционного Суда РФ от 04.04.2002 № 8-П «По делу о проверке конституционности отдельных положений Федерального закона “Об общих принципах организации законодательных (представительных) и исполнительных органов государственной власти субъектов Российской Федерации” в связи с запросами Государственного Собрания (Ил Тумэн) Республики Саха (Якутия) и Совета Республики Государственного Совета - Хасэ Республики Адыгея» // Вестник Конституционного Суда РФ. 2002. № 5. Доступ из СПС «Консультант Плюс» (дата обращения: 12.11.2015).

15. Гаджиев Г. А. Реализация решений Конституционного Суда РФ. Конференция по мониторингу законодательства и правоприменения в РФ. Санкт-Петербург, 25 июня 2010 г. URL: http://rapsinews.ru/judicial_analyst/20100629/250313343.html.

16. Малюшин А. А. Указ. соч. Доступ из СПС «Консультант Плюс» (дата обращения: 12.11.2015).

17. Общая теория государства и права: Академический курс: В 2 т. / Под ред. проф. М. Н. Марченко. М.: Зерцало, 1998. Т. 2: Теория права.

18. Постановление Конституционного Суда РФ от 13.11.1995 № 13-П «По делу о проверке конституционности части пятой статьи 209 Уголовно-процессуального кодекса РСФСР в связи с жалобами граждан Р. Н. Самигуллиной и А. А. Апанасенко» // Собрание законодательства РФ. 20.11.1995. № 47. Ст. 4551. Доступ из СПС «Консультант Плюс» (дата обращения: 12.11.2015).

19. Постановление Конституционного Суда РФ от 25.01.2001 № 1-П «По делу о проверке конституционности положения пункта 2 статьи 1070 Гражданского кодекса Российской Федерации в связи с жалобами граждан И. В. Богданова, А. Б. Зернова, С. И. Кальянова и Н. В. Труханова» // Собрание законодательства РФ. 12.02.2001. № 7. Ст. 700. Доступ из СПС «Консультант Плюс» (дата обращения: 12.11.2015).

20. Указ Президента РФ от 03.06.1996 № 803 «Об Основных положениях региональной политики в Российской Федерации» // Собрание законодательства РФ. 03.06.1996. № 23. Ст. 2756. Доступ из СПС «Консультант Плюс» (дата обращения: 12.11.2015).

21. Трошев А. Принятие закона о механизме исполнения решений Конституционного Суда Российской Федерации // Конституционное право: Восточное обозрение. 2002. № 2 (39). С. 40.

22. Федеральный конституционный закон от 15.12.2001 № 4-ФКЗ «О внесении изменений и дополнений в Федеральный конституционный закон “О Конституционном Суде Российской Федерации”» // Собрание законодательства РФ. 17.12.2001. № 51. Ст. 4824. Доступ из СПС «Консультант Плюс» (дата обращения: 12.11.2015).

23. Стеркин Ф., Эбзеев Б. За все эти годы ни одному суду не понадобились гарантии неприкосновенности // Страна.ru. 17.12.2001. URL: http://www.strana.ru/text/stories/01/11/22/2076/94679.html (дата обращения: 12.11.2015).

24. Морщакова Т. Г. Российское правосудие в контексте судебной реформы. М., 2004.

25. Мазуров А. В. Комментарий к Федеральному конституционному закону «О Конституционном Суде Российской Федерации». 2-е изд., перераб. и доп. М.: Частное право, 2009. Доступ из СПС «Консультант Плюс» (дата обращения: 15.11.2015).

26. Омаров С. М. Проблемы исполнения Федеральным Собранием решений Конституционного Суда Российской Федерации // Конституционное и муниципальное право. 2012. № 1. С. 52-58. Доступ из СПС «Консультант Плюс» (дата обращения: 15.11.2015).

27. Александрова М. А. Пути разрешения проблемы неисполнения актов Конституционного Суда Российской Федерации // Российский судья. 2014. № 11. С. 35-39. Доступ из СПС «Консультант Плюс» (дата обращения: 15.11.2015).

28. Петров А. А. Правовая основа организации и деятельности Конституционного Суда Российской Федерации: тенденции и перспективы модернизации // Конституционное право и политика: Сб. материалов междунар. науч. конф.: Юридический факультет МГУ имени М.В. Ломоносова, 28-30 марта 2012 г. / С. А. Авакьян, Д. С. Агапов, Н. И. Акуев и др.; отв. ред. С. А. Авакьян. М.: Юрист, 2012. Доступ из СПС «Консультант Плюс» (дата обращения: 15.11.2015).

29. Кокотов А. Н. Исполнение решений Конституционного Суда Российской Федерации // Журнал российского права. 2013. № 5. С. 90-101. Доступ из СПС «Консультант Плюс» (дата обращения: 15.11.2015).

30. Бондарь Н. С. Нормативно-доктринальная природа решений Конституционного Суда РФ как источников права // Журнал российского права. 2007. № 4.

31. Федеральный закон от 02.10.2007 № 229-ФЗ (ред. от 29.06.2015) «Об исполнительном производстве» // Собрание законодательства РФ. 08.10.2007. № 41. Ст. 4849. Доступ из СПС «Консультант Плюс» (дата обращения: 15.11.2015).

\section{References (transliterated):}

1. Vstavskaya I. M., Savchenko S. A. Ispolnitel'noe proizvodstvo: Ucheb. posobie. 2-e izd., pererab. i dop. M.: Prospekt, 2010. Dostup iz SPS «Konsul'tant Plyus» (data obrashcheniya: 12.11.2015).

2. Zor'kin V. D. Rossiya i Konstitutsiya v XXI veke. Vzglyad s Il'inki. M., 2007.

3. Nechaeva Zh. V. Voprosy effektivnosti ispolneniya reshenii Konstitutsionnogo Suda Rossiiskoi Federatsii // Zhurnal konstitutsionnogo pravosudiya. 2008. № 5. S. 24-30. Dostup iz SPS «Konsul’tant Plyus» (data obrashcheniya: 12.11.2015).

4. Vasilevich G. A. Realizatsiya reshenii Konstitutsionnogo Suda Respubliki Belarus' - vazhnoe uslovie formirovaniya sovremennoi pravovoi sistemy // Natsional'naya gosudarstvennost' i evropeiskie integratsionnye protsessy: Sb. nauch. tr. V 2 t. / Belorus. gos. un-t. Minsk, 2008. T. 1: Natsional'noe zakonodatel'stvo i ego garmonizatsiya s pravom Evropeiskogo soyuza. 
DOI: $10.7256 / 1811-9018.2015 .12 .17310$

При цитировании этой статьи сноска на dоі обязательна

Судебная власть

5. Malyushin A. A. Konstitutsionno-sudebnoe pravotvorchestvo v Rossiiskoi Federatsii: problemy teorii i praktiki: Monografiya. M.: Yurist, 2013. Dostup iz SPS «Konsul’tant Plyus» (data obrashcheniya: 12.11.2015).

6. Gadzhiev G. A. Realizatsiya reshenii Konstitutsionnogo Suda RF. Konferentsiya po monitoringu zakonodatel'stva i pravoprimeneniya v RF. Sankt-Peterburg, 25 iyunya 2010 g. URL: http://rapsinews.ru/judicial_analyst/20100629/250313343.html.

7. Malyushin A. A. Ukaz. soch. Dostup iz SPS «Konsul'tant Plyus» (data obrashcheniya: 12.11.2015).

8. Troshev A. Prinyatie zakona o mekhanizme ispolneniya reshenii Konstitutsionnogo Suda Rossiiskoi Federatsii // Konstitutsionnoe pravo: Vostochnoe obozrenie. 2002. № 2 (39). S. 40.

9. Sterkin F., Ebzeev B. Za vse eti gody ni odnomu sudu ne ponadobilis' garantii neprikosnovennosti // Strana.ru. 17.12.2001. URL: http://www.strana.ru/text/stories/01/11/22/2076/94679.html (data obrashcheniya: 12.11.2015).

10. Morshchakova T. G. Rossiiskoe pravosudie v kontekste sudebnoi reformy. M., 2004.

11. Mazurov A. V. Kommentarii k Federal'nomu konstitutsionnomu zakonu «O Konstitutsionnom Sude Rossiiskoi Federatsii». 2-e izd., pererab. i dop. M.: Chastnoe pravo, 2009. Dostup iz SPS «Konsul'tant Plyus» (data obrashcheniya: 15.11.2015).

12. Omarov S. M. Problemy ispolneniya Federal'nym Sobraniem reshenii Konstitutsionnogo Suda Rossiiskoi Federatsii // Konstitutsionnoe i munitsipal'noe pravo. 2012. № 1. S. 52-58. Dostup iz SPS «Konsul’tant Plyus» (data obrashcheniya: 15.11.2015).

13. Aleksandrova M. A. Puti razresheniya problemy neispolneniya aktov Konstitutsionnogo Suda Rossiiskoi Federatsii // Rossiiskii sud’ya. 2014. № 11. S. 35-39. Dostup iz SPS «Konsul’tant Plyus» (data obrashcheniya: 15.11.2015).

14. Petrov A. A. Pravovaya osnova organizatsii i deyatel'nosti Konstitutsionnogo Suda Rossiiskoi Federatsii: tendentsii i perspektivy modernizatsii // Konstitutsionnoe pravo i politika: Sb. materialov mezhdunar. nauch. konf.: Yuridicheskii fakul'tet MGU imeni M.V. Lomonosova, 28-30 marta 2012 g. / S. A. Avak'yan, D. S. Agapov, N. I. Akuev i dr.; otv. red. S. A. Avak’yan. M.: Yurist, 2012. Dostup iz SPS «Konsul'tant Plyus» (data obrashcheniya: 15.11.2015).

15. Kokotov A. N. Ispolnenie reshenii Konstitutsionnogo Suda Rossiiskoi Federatsii // Zhurnal rossiiskogo prava. 2013 . № 5. S. 90-101. Dostup iz SPS «Konsul'tant Plyus» (data obrashcheniya: 15.11.2015).

16. Bondar' N. S. Normativno-doktrinal'naya priroda reshenii Konstitutsionnogo Suda RF kak istochnikov prava // Zhurnal rossiiskogo prava. 2007. № 4. 